\title{
Oldrich Bures, Private Security Companies. Transforming Politics and Security in the Czech Republic
}

(Basingstoke: Palgrave Macmillan, 2015, pp. X, 176, ISBN 978-1-137-47752-1 (hbk)

\author{
Reviewed by Cyril Magnon-pujo \\ Centre Européen de Sociologie et de Science Politique / CESSP - Paris \\ Université Paris 1 Pantheon-Sorbonne
}

The privatisation of security and the development of private security companies have become a common theme in International Relations' studies since 2005. In the aftermath of the War on Terror and the intervention in Iraq, scholars have shown a growing interest for the generic description of private security actors, trying first to explain what this 'new' industry is and where it came from. A second period in the study of private security companies (PSCs) led to more analytical works on the consequences of this privatisation, while generally taking for granted an opposition between the State and private industry. Oldrich Bures' book belongs however to a third category. In the continuation of Elke Krahmann's, Anna Leander's, Rita Abrahamsen and Michael Williams' research (references that he frequently summons), it reevaluates the forms and impact of security privatisation, through the reconsideration of the traditional distinctions and the empirical investigation of the "rearticulation of powers and relations between the public and the private" (p. 9). It offers a stimulating perspective on the issue of contemporary security governance, thanks to the detailed analysis of the practices of PSCs in the Czech Republic.

Head of the Center for Security Studies at the Metropolitan University of Prague, Oldrich Bures has done considerable research on private security companies, before focusing on the specific case of the Czech Republic. He offers here, all along this short manuscript, a welcomed synthesis of his work, partly published in Czech journals. Bures' approach of the subject - and contribution to the study of private security - is explicit and clearly presented. His book is indeed an attempt to apply Abrahamsen and Williams' "global security assemblage" framework - that is, "transnational structures and networks in which a range of different actors and normativities interact, cooperate and compete to produce new institutions, practices and forms of deterritorialized security governance" (p. $\left.8^{1}\right)$ - in order to analyse PSCs' activities in the Czech Republic, and consequently test their model in the context of a post-communist country (rather than African States). As such, Bures follows their 2011 analysis, and looks at this new geography of power, where the State crumbles without fading away and power rearticulates along new institutions linking public

1 Quoted from R. Abrahamsen \& M. Williams, Security Beyond the State. Private Security in International Politics (Cambridge: Cambridge University Press, 2015), p. 90. 
and private actors but also the global and local level. He concurs with Abrahamsen and Williams' development when praising their introduction of Pierre Bourdieu's field theory to take into account power struggles and the importance of capital and habitus in the functioning of such global security assemblages, even if calling for some adjustments. Challenging the ordinary idea of a rise of private security actors as a synonym of a State's decline, Bures proposes in his book a well-documented study of the contemporary rearticulation of power, in the case of security. Through his presentation of the Czech security assemblage, he reveals the growing influence of PSCs on politics and security, and illustrates the intertwinement of the global and the local, the private and the public.

With an extensive private security sector, a rapid disengagement of the State, an absence of specific regulation, and PSCs founding political parties, the Czech Republic offers a rather unique and under-researched case study to assess the impact of the private security sector on politics and security. Accordingly, in line with AngloSaxon publication's practices, Bures offers first a development on his theoretical and methodological "inspiration" (chapter 2, p. 28,). Before his presentation of the Czech security assemblage, he therefore returns to the "various strands of assemblage thinking" (p. 13), to conclude on the suitable use of Abrahamsen and Williams' "Bourdieu-enhanced global security assemblage" framework (p. 35), which is alone able to deal with power and change in the new practices of security. Sometimes elliptic when tracing back assemblage thinking to Gilles Deleuze and Pierre-Felix Guattari - without taking into account Norbert Elias, Niklas Luhmann or Pierre Bourdieu's works on the differentiation of societies - and when referring to the contemporary concept - especially for readers unfamiliar with security or globalisation studies Bures mentions assemblage theories without really engaging with them. He relies on Christian Bueger to recall that assemblage thinking (which embraces multiplicity, focuses on practices of relating and order, mixes material and symbolic expressivity, and considers simultaneously territorialisation and de-territorialisation ${ }^{2}$ ) should first and foremost be seen as a relevant empirical tool to study interactions at the international level, if only combined with a "Bourdieusian analysis of forms of capital and power" (p.21). Interested in the fluidity and contentious nature of assemblages which bring together disparate and heterogeneous elements, Bures finds indeed in Bourdieu's work tools - capital, field, habitus, doxa - that help him investigate the disassembling and the constantly evolving rearticulation of the Czech State around specific private actors and global logics.

Taking most of his interviews with Czech PSCs' managers (regularly quoted) and officials of the Czech administration, Bures properly enters his case-study when describing the seven characteristics of the Czech security assemblage (chapter 3). Developed in the aftermath of a shock therapy leading to a rapid and unregulated opening to the market after a State-led economy, the Czech security field is described as non-lethal, fuelled by numerous registered companies (6500 currently, of which 200 or 300 are probably active), internally fragmented, home of international PSCs operating locally, and offering mainly protective services for individuals and properties. According to Bures, it is also characterised by its absence of export and its lack of specific legal regulation regarding PSCs. Going further, the author

2 Cf. C. Bueger, 'Thinking Assemblages Methodologically: Some Rules of Thumb', in M. Acuto \& S. Curtis (eds.), Reassembling International Theory: Assemblage Thinking and International Relations (Basingstoke: Palgrave Macmillan, 2014), pp. 58-66. 
elaborates on the multidimensional power gained by Czech PSCs at the heart of this assemblage, through the material, but also symbolic and cultural capital they accumulated over the last twenty years. With their economic power, they challenge the State and present themselves as the relevant, expert and technological option to overcome its weaknesses. As such, Czech PSCs reinforce their symbolic capital and tend to maximise their cultural one.

This rearticulation of security from public to private actors implies a new role for State and PSCs, and reveals the influence of the global level in the development of local assemblage. It has two consequences that Bures successively analyses in separate chapters. The first one regards politics (chapter 4). According to Bures, Czech politics is indeed 'transformed' by the growing power of PSCs and their intertwinement with the public sphere. He analyses the influence exercised by private companies on the decision-making process (especially regarding regulation), but also on the constitution of the political field itself since PSCs enter this arena in order to advance their economic interests. Speaking of a "reverse revolving door" (p. 80), Bures illustrates the blurring of the public/private boundary when he exposes the case of a PSC, which founded a political party, won elections and ended with major ministerial positions, consequently importing into Czech politics the concept of "party as business model" (p. 983). As a result of the Czech security assemblage empowering PSCs, Bures therefore demonstrates how politics has changed, but also how it became a stake for private agents. They link the public and the private to serve their interests and, consequently devote to the former a role despite an apparent privatisation. The second consequence of the Czech security assemblage highlighted in the book concerns security (chapter 5). From its implementation to its definition and understanding, the emergence of PSCs has modified security in the Czech Republic in the last twenty years. Operationalising once again a theoretical model, Bures applied here Krahmann's work on the commodification of security ${ }^{4}$ to prove how PSCs have transformed security - through their offer and practices, and in the absence of the State - into a private, excludable, rival and a-political good available on a market. Such a reconceptualisation of security is described as its possible displacement and transformation, the demand for security being now addressed to private actors and not anymore to the State, which tends to copy PSCs' strategies. In Bures' analysis, the development of a specific Czech security assemblage thus implies profound shifts in the relation between the public and the private, but also between State and society. Such a rearticulation of power is finally considered in the long run, in order to assess how far security privatisation will go in the Czech Republic, including in 'inherently governmental' domains where the State is supposed to defend its prerogatives and prove its legitimacy as a security provider.

Moving away from sensationalist studies of PSCs interested in war zones and in the mercenary training, Bures provides in his book a convincing demonstration of the shifting practices regarding security in the Czech Republic. As such, he offers an illustration of the development, functioning and consequences of new security assemblages, which State and private actors conduct to redefine their relations. The State plays indeed a central role in its disassembling, but also in the reassembly of

3 In reference to J. Hopkin \& C. Paolucci, 'The Business Firm Model of Party Organisation: Cases from Spain and Italy’, European Journal of Political Research, 35(3), 1999, pp. 307-339.

4 E. Krahmann, 'Security: Collective Good or Commodity ?', European Journal of International Relations, 14 (3), 2008, pp. 379-404. 
powers as it appears as a provider, a symbolic agent and a level of authority duly considered by PSCs, whose power and influence grows and has an impact on politics and security. More than the simple operationalisation of a contemporary concept, Bures proposes a stimulating side-step when offering a case-study in Eastern Europe, rarely considered on such topics. This allows him to amend the original "Bourdieuenhanced global security assemblage" framework, and insist on its changing nature and, more importantly, on its embeddedness in the social and legal context. Here, the precedents of a State-led economy and a shock therapy play an important part in the construction of an "intriguing" and specific Czech security assemblage (p. 157), whose characteristics cannot all be explained by the model that Bures follows.

One can then regret the juxtaposition of the conceptual frameworks used, but not always connected. Attractive and relevant, the idea of enhancing the global security assemblage theory with Bourdieusian concepts leads for instance Bures to speak alternatively about assemblage(s), markets and fields. A closer investigation on the Czech administration's attitude could be a key to document power struggles outside of the private security industry and, consequently, re-evaluate the State's rearticulation in regards to private but also public agents' practices, dispositions and interests. This however should not silence Bures grounded analysis of the consequences of security privatisation, leading to a reconceptualisation of security and the transformation of the local political field as a result of PSCs' new multidimensional authority. 